\title{
Loricate choanoflagellates (Acanthoecida) from warm water seas. IV. Cosmoeca Thomsen
}

Thomsen, Helge Abildhauge; Østergaard, Jette Buch

Published in:

European Journal of Protistology

Link to article, DOI:

10.1016/j.ejop.2019.125632

Publication date:

2019

Document Version

Peer reviewed version

Link back to DTU Orbit

Citation (APA):

Thomsen, H. A., \& Østergaard, J. B. (2019). Loricate choanoflagellates (Acanthoecida) from warm water seas. IV. Cosmoeca Thomsen. European Journal of Protistology, 71, [125632].

https://doi.org/10.1016/j.ejop.2019.125632

\section{General rights}

Copyright and moral rights for the publications made accessible in the public portal are retained by the authors and/or other copyright owners and it is a condition of accessing publications that users recognise and abide by the legal requirements associated with these rights.

- Users may download and print one copy of any publication from the public portal for the purpose of private study or research.

- You may not further distribute the material or use it for any profit-making activity or commercial gain

- You may freely distribute the URL identifying the publication in the public portal 


\section{Journal Pre-proof}

Loricate choanoflagellates (Acanthoecida) from warm water seas. IV. Cosmoeca Thomsen

Helge Abildhauge Thomsen, Jette Buch Østergaard

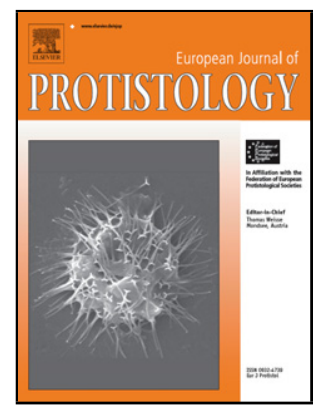

PII:

S0932-4739(19)30069-0

DOI:

https://doi.org/10.1016/j.ejop.2019.125632

Reference:

EJOP 125632

To appear in:

Received Date: 8 April 2019

Revised Date: $\quad 19$ June 2019

Accepted Date: 2 July 2019

Please cite this article as: Thomsen HA, Østergaard JB, Loricate choanoflagellates (Acanthoecida) from warm water seas. IV. Cosmoeca Thomsen, European Journal of Protistology (2019), doi: https://doi.org/10.1016/j.ejop.2019.125632

This is a PDF file of an article that has undergone enhancements after acceptance, such as the addition of a cover page and metadata, and formatting for readability, but it is not yet the definitive version of record. This version will undergo additional copyediting, typesetting and review before it is published in its final form, but we are providing this version to give early visibility of the article. Please note that, during the production process, errors may be discovered which could affect the content, and all legal disclaimers that apply to the journal pertain.

(c) 2019 Published by Elsevier. 


\section{Loricate choanoflagellates (Acanthoecida) from warm water seas. IV. Cosmoeca Thomsen}

Helge Abildhauge Thomsen ${ }^{\mathrm{a}}$ and Jette Buch $\varnothing_{\text {stergaard }}{ }^{\mathrm{b}}$

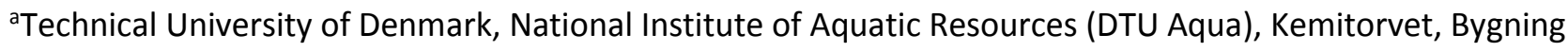
201, DK 2800 Kgs. Lyngby, Denmark / hat@aqua.dtu.dk

${ }^{b} \mathrm{~N} \varnothing$ rrebrogade 52a 5th, 2200 Copenhagen N, Denmark

\section{Abstract}

Aided by an extensive collection of specimens from warm water seas, it has been possible to revisit the loricate choanoflagellate genus Cosmoeca. While the generic type $C$. norvegica and also $C$. ventricosa sensu stricto have been described from temperate North Atlantic realms and share a cosmopolitan distribution, the remaining species and morphotypes of Cosmoeca are largely confined to warmer waters. The new data broadly validates the initial circumscription of species of Cosmoeca. The persisting taxonomic puzzle with respect to $C$. ventricosa, which in addition to the core type accommodates no less than five different morphotypes (form A-E), has been further elucidated. The Cosmoeca paper is part of a 'monographic' series of warm water loricate choanoflagellate contributions in progress, where the aim is to provide the best possible account of warm water species diversity, based on traditional light and electron microscopical techniques, as a tool for future identification work based on microscopy, and in support of the work in progress with establishing a quality assured molecular tool for future recognition of diversity.

Keywords: Acanthoecida; Cosmoeca; Loricate choanoflagellates; Warm water seas 


\section{Introduction}

The genus Cosmoeca Thomsen in Thomsen and Boonruang, 1984, was established to circumscribe a handful of species that distinguished themselves sufficiently to be pulled away from the Pleurasiga complex, which was generally acknowledged to be taxonomically incoherent. This was due to in particular uncertainties relating to the actual identity of the Adriatic Sea type species Pleurasiga orculaeformis Schiller, 1925 (Schiller 1925; loc. cit. PI. 4, Fig. 24). Attempts had been made (Leadbeater 1973) to redescribe the Pleurasiga type species based on TEM analysis of material sampled in the Adriatic Sea (Kastel bay and the Bay of Kotor). However, the similarities between $P$. orculaeformis Schiller and $P$. orculaeformis sensu Leadbeater (1973; loc. cit. Pl. 14 a-d) were too little pronounced to convincingly solve the identity enigma of the Pleurasiga type species (Thomsen 1976; Thomsen and Boonruang 1984). Thomsen and Boonruang (1984) consequently redescribed Pleurasiga orculaeformis sensu Leadbeater, 1973, as Cosmoeca ventricosa Thomsen in Thomsen and Boonruang, 1984. The genus Cosmoeca was typified by C. norvegica Thomsen in Thomsen and Boonruang 1984, a globally distributed taxon which had previously been referred to under the heading sp. 'N' (Moestrup 1979). The Pleurasiga taxonomical riddle, which as indicated above is intimately connected to the creation of the genus Cosmoeca, remains unsolved. However, as discussed by Thomsen and $\emptyset$ stergaard (2019a) it becomes more and more obvious that the closest match of $P$. orculaeformis is in fact among species presently allocated to the genus Polyfibula Manton and Bremer, 1981 (Manton and Bremer 1981). However, a further complication here exists with reference to the Campanoeca Throndsen, 1974 type species C. dilatata Throndsen, 1974 which is only known from light microscopy (Throndsen 1974) but obviously intimately related to the Polyfibula species cluster, and hence also Pleurasiga orculaeformis.

So far just a single species of Cosmoeca (C. ventricosa) has been sequenced (Nitsche et al. 2017), and here Cosmoeca ventricosa and Bicosta minor were found to cluster together with Acanthocorbis unguiculata. Although this branching pattern had high bootstrap support, the different morphology of 
these species indicates that a subsequent incorporation of additional sequences representing each genus is likely to cause the pattern to change (Nitsche et al. 2017).

Species of Cosmoeca have been repeatedly reported in regional species surveys, e.g. Thomsen et al. (1991; Pacific Ocean off Monterey Bay, California); Tong (1997a; Southampton Waters, English Channel) and Menezes (2005; Petaquamscott River, Rhode Island, USA). A more thorough morphometric analysis of in particular C. ventricosa has been provided based on Antarctic material (Thomsen et al. 1990) and more recently on Arctic material (Thomsen and Østergaard 2017).

This paper is part of a series of loricate choanoflagellate taxonomical contributions that are based on extensive collections of previously unpublished material from warm water habitats (Thomsen and $\emptyset$ stergaard 2019a-c). Here we report on the occurrence of 5 species of Cosmoeca, with particular emphasis on the variability observed in C. ventricosa.

\section{Material and Methods}

The material that constitutes the background for this and a series of papers on warm water acanthoecid choanoflagellates was collected over a period of 35 years. The geographic origin of samples is recorded in Fig. 1. See Thomsen and $\varnothing$ stergaard (2019a) for information on each of the collection sites and sampling campaigns.

The general protocol for processing water samples for the light microscope (LM) and transmission electron microscope (TEM) was according to Moestrup and Thomsen (1980) and Thomsen (1982). For details on sample processing, preparational issues and microscopes used see Thomsen and $\varnothing$ stergaard (2019a).

The material examined here is dried which means that the natural 3-D structures have collapsed to become 2-D structures, leading to an artefactual expansion of in particular the lorica width. While several structures can still be measured with confidence, e.g. lorica chamber height and the length of spines and 
pedicels, it does imply that certain values such as lorica diameter, typically at the level of the transverse costa(e), cannot be measured directly but only calculated from measurements of the circumference. This approach has been taken in the species descriptions below.

Efforts are made to make use of a concise terminology when describing lorica features and we follow the standards that have developed in the course of dealing with these organisms; see e.g. Leadbeater (2015; loc. cit. chapter 4 and glossary p. 278) and Thomsen and Buck (1991).

An annotated TEM whole mount of $C$. norvegica (Fig. 2 ) is prepared to simplify the interpretation of text and images.

A reviewer has vigilantly commented on that there is a systematic (mirror image) difference between Cosmoeca images published in Thomsen and Boonruang (1984) and those originally included here. In illustrations provided by Thomsen and Boonruang (1984) the overlaps between adjacent strips forming the anterior transverse costa when seen from the outer surface take the following form in a clockwise direction. The left-hand end of a costal strip underlaps the right-hand end of the adjacent strip (e.g. Thomsen and Boonruang 1984, loc. cit. Fig. 39). When this junction interacts with a longitudinal costa, the result in a dried specimen is to produce a small triangle on the right-hand side of the longitudinal costal strip (when seen from the outer surface; see e.g. Fig. $4 \mathrm{i}$, u; arrows). In the middle transverse costa, when seen from the outer surface and in a clockwise direction the left-hand end of a costal strip overlaps the right-hand end of the adjacent costal strip. As with the anterior transverse costa, when the junction interacts with a longitudinal costa the triangle is on the right-hand side of the longitudinal costa (see e.g. Fig. 4i; arrowheads). When the anterior and middle transverse costae are seen from the inner surface of the lorica the respective triangles are located on the left-hand side of a longitudinal costa. It should be noted that the small triangles referred to are artefactual but are, nevertheless, very consistent in location. There is a high level of consistency in the substructure of choanoflagellate loricae which reflects the logistics and assembly of the lorica (Leadbeater 2015), and the Cosmoeca loricae as depicted in Thomsen and Boonruang (1984) corroborated the general picture. It is not likely that there is a genuine 
natural variation in orientation which is systematically reflected in sampling efforts separated by less than two decades. When scrutinizing the problem outlined above, we have found that the orientation of the images differs in parallel with the microscope used. It is therefore highly likely, that there is an unknown reversal of the images at some stage relevant to the JEOL 100 SX microscope. This microscope was used to examine the vast majority of the material that we build upon in the currently ongoing survey of warm water loricate choanoflagellate biodiversity.

A repeated scanning of negatives from the two microscopes most frequently used (JEM-T8 and JEM100SX) have confirmed that the reversal issue is not simply brought about while transferring analogue to digital information. We have consistently applied the same procedure while preparing grids and inserted these into the microscope with the material facing upwards. However, it remains a possibility that the end of the grid holder when placed in the microscope is perhaps rotated vertically, or that a different number or configuration of lenses within the column can cause an image to be reversed.

Accepting that all biological evidence points to the fact that we are here dealing with a consistent, as yet unresolved, technical issue, we have horizontally flipped all JEOL-100SX images (i.e. Fig. 4i, t, u, v; Fig. 5a, r; Fig. 7m; Fig. 11h, i, l; Fig. 13a, b) to reproduce the same lorica symmetry as evidenced by Thomsen and Boonruang (1984) and correspondingly supported by observations meticulously detailed by Leadbeater (2015).

The above findings and conclusions have ramifications beyond the current publication. While describing Stephanoeca andemanica is was discovered and discussed that two specimens illustrated (Thomsen and $\varnothing$ stergaard 2019c; loc. cit. Fig. 8a, b) were found to be mirror images with reference to lorica assembly patterns. These images come from two different electron microscopes, which now only confirms the general hypothesis and conclusions above. Figure 8b in Thomsen and $\emptyset$ stergaard (2019c) is a mirror image and should thus be reversed if scrutinized for detailed lorica features.

While a correct and non-inverted reproduction of an image is essential when it comes to analysing and confirming universal patterns in lorica assembly, the fact that a certain image has been unintentionally 
horizontally flipped is not essential for species identification, which is based on larger scale features than those referred to above. However, to remedy the situation with reference to mirror images included in Thomsen and $\emptyset$ stergaard (2019a-c) we have included here as supplementary information (Revised plates manuscripts 1-3) complete sets of the illustrations originally provided (Thomsen and Østergaard 2019a-c) in which the images that have been horizontally flipped are clearly marked. 


\section{Results and Discussion}

The Cosmoeca lorica is barrel- shaped or conical and comprises 9-12 longitudinal costae and two or three transverse costae (Fig. 2). All costal strips are narrow rods. The longitudinal costae each comprises three or four costal strips and cross at the junctions between anterior transverse costal strips (abutting junctions). The anterior transverse costa and the middle transverse costa are inside the longitudinal costae. The protoplast is firmly placed in the posterior tapering part of the lorica. A delicate membrane surrounds the protoplast and part of the collar, mediating contact with the lorica. The flagellum is usually long and extends out of the lorica in some species. The longitudinal costae may protrude above the anterior transverse costa as short simple spines. Sometimes the spines are more elaborate and furnished with onesidedly developed angular thorns (C. ventricosa form ' $\mathrm{B}$ '). A short simple pedicel is reported from $C$. ventricosa form ' $D$ ' (Thomsen et al. 1990), whereas in C. takahashii (Thomsen et al. 1990) there is a complete ring of posteriorly projecting costal strips emanating from the third anterior transverse costa (counted from the anterior lorica end). Tectiform division is verified from the presence in all species (with the possible exception of $C$. phuketensis) of accumulations of supernumerary costal strips in the collar region.

So far only 6 species of Cosmoeca have been described, i.e. C. norvegica Thomsen in Thomsen and Boonruang, 1984 (Fig. 3a), C. subulata Thomsen in Thomsen and Boonruang, 1984 (Fig. 3b), C. ceratophora Thomsen in Thomsen and Boonruang, 1984 (Fig. 3c), C. phuketensis Thomsen in Thomsen and Boonruang, 1984 (Fig. 3d), C. takahashii Thomsen in Thomsen et al., 1990 (Fig. 3e; = Pleurasiga sp. \#4 (Takahashi 1981)), and C. ventricosa Thomsen in Thomsen and Boonruang, 1984 (Fig. 3f). A number of minor variations on the $C$. ventricosa theme have tentatively been referred to as form 'A-E'. While form 'A-C' (Fig. 3g-i) were introduced by Thomsen and Boonruang (1984), the form 'D' (Fig. 3j) was established by Thomsen et al. (1990) and form ' $E$ ' (Fig. 3k) by Thomsen and $\varnothing$ stergaard (2017). The only species not covered below is $C$. takahashii which is so far distributionally confined to polar regions (Takahashi 1981, Thomsen et al. 1990, Thomsen and Østergaard 2017). 
Species of Cosmoeca (from 'cosmos' (Greek, in beautiful order) and 'oicos' (Greek, house)) are easily recognized also in the LM due to lorica dimensions, and the overall simple and consistent lorica features that characterizes each of the species presently allocated to the genus.

\section{Cosmoeca norvegica (Fig. 4a-i)}

In this species the number of longitudinal costae is invariably 10 (Table 1) and each of these comprises four costal strips. This also applies when examining $C$. norvegica specimens from outside the warm water ocean realms. The one feature that immediately distinguishes $C$. norvegica is the fact that the distance between the two anterior transverse costae equals 1.5 longitudinal costal strips (Fig. $4 \mathrm{i}$ ) a feature which is also easily observed in the LM (Fig. 4a-h). The two anterior transverse costae are of equal size (Table 1), and there are no anterior spines. It is evident from Table 1 and Fig. 6a that $C$. norvegica shows little morphometric variability across the regions sampled.

\section{Cosmoeca phuketensis (Fig. 4j-v)}

The tiny conical lorica invariably comprises nine longitudinal costae (Table 1), and each of these spans three costal strips. There are only two transverse costae, one at the anterior lorica end, and a second transverse costa at the level of the protoplast and removed posteriorly from the anterior ring corresponding to the length of two longitudinal costal strips. The posterior transverse costa typically comprises four costal strips (Fig. $4 p, u, v$ ). There are no anterior spines and the flagellum typically extends far out of the lorica (Fig. 4j, k). Cosmoeca phuketensis displays significant morphometric variability (Fig. 4j-s) which is concretized in Table 1 and Fig. 6b. Specimens from the Pacific Ocean are larger than the others and those from West Australia among the smallest. As evidenced from the collection of images in Fig. 4j-s this taxon is easily distinguished also in the LM.

\section{Cosmoeca ceratophora (Fig. 5a-j)}


The conical lorica invariably comprises 10 longitudinal costae (Table 1), and each if these encompasses four costal strips (Fig. 5a). There are two transverse costae. The anterior costa crosses approximately midway along the anterior longitudinal costal strips forming conspicuous anterior lorica spines. The tiny posterior transverse costa is displaced posteriorly equal to the length of 2.5 longitudinal costal strips (Fig. 5a) and typically comprises only four transverse costal strips. Cosmoeca ceratophora displays some morphometric variability (Table 1; Fig. 6c), yet without any obvious region-specific pattern.

\section{Cosmoeca subulata (Fig. 5k-r)}

The conical lorica typically comprises 10 longitudinal costae (Table 1), and each of these contains four costal strips. In two out of 23 specimens analysed $(<9 \%)$ there were 11 longitudinal costae. There are three transverse costae. The anterior costa crosses the longitudinal costal strips subapically $(1 / 4$ costal strip length) resulting in the formation of short anterior spines. These are thus significantly shorter than those found in C. ceratophora (Fig. 5a). The middle transverse costa (six or seven costal strips) crosses at the junctions between the second and the third longitudinal costal strip counted from the anterior lorica end, and the posterior transverse costa (four costal strips) one costal strip further down at the junctions between the third and fourth longitudinal costal strip. Cosmoeca subulata shows overall little morphometric variability (Table 1 and Fig. 6d) although specimens from West Australia (Fig. 5k-n) tend to be slightly larger than those from the Pacific Ocean (Fig. 5o-q).

\section{Cosmoeca ventricosa incl. form ' $A$ ' (Figs 7, 8)}

The $C$. ventricosa lorica is barrel-shaped and comprises 8-11 longitudinal costae. Loricae with 10 longitudinal costae account for $72.6 \%$ of all specimens examined $(n=208)$ while nine longitudinal costae occur in $23.1 \%$ of our specimens (Fig. 10a; inset). Each longitudinal costa encompasses four costal strips. There are three transverse costae. The anterior transverse costa and a second costa placed between the junctions between the second and the third longitudinal costal strips counted from the anterior lorica end are of approximately the same size. The posterior transverse costa (located between longitudinal costal 
strip 3 and 4) has a reduced diameter and comprises four or five costal strips. There are in C. ventricosa sensu stricto no spines anteriorly.

When this species was first described (Thomsen and Boonruang 1984) the type specimen was selected from a cluster of large specimens found in Danish coastal samples. The average lorica height was here 26.2 $\mu \mathrm{m}$ (range: $23-31 \mu \mathrm{m}$ ), the average diameter of the anterior transverse costa $22.4 \mu \mathrm{m}$ (range: 18-27 $\mu \mathrm{m}$ ) and the number of longitudinal costae varied from 9-12. Specimens of almost the same size (lorica height: 25-27 $\mu \mathrm{m}$ / diam. anterior transv. costa: 18-20.8 $\mu \mathrm{m}$ / 9-11 longitudinal costae) were reported also from Thailand coastal waters (Thomsen and Boonruang 1984). The C. ventricosa form ' $A$ ' was described alongside $C$. ventricosa and in particular based on specimens from the Andaman Sea, Thailand. This form is distinctively smaller than $C$. ventricosa sensu stricto (lorica height: $15 \mu \mathrm{m}$ / diam. anterior transv. costa: 10$12.5 \mu \mathrm{m}$ ) and has in Thailand waters invariably 10 longitudinal costae. Form ' $\mathrm{A}$ ' specimens from other regions (Greenland, Croatia) have 9-11 longitudinal costae (Thomsen and Boonruang 1984).

While both size extremes are found also in the material examined here and illustrated using material from West Australia (Fig. 7a-I), the Gulf of California (Fig. 7m-o), and the Sargasso Sea (Fig. 8), it also becomes evident that the size variability is almost continuous rendering it complicated to differentiate between size-specific forms. Site-specific details on lorica size variability in conjunction with lorica constructional variables, i.e. the number of longitudinal costae, are provided in a panel of graphs (Fig. 9). Specimens from the Sargasso Sea, the Gulf of California and the Pacific Ocean samples (with the exception of a single specimen) have nine or 10 longitudinal costae only (Fig. 9c-e), while Andaman Sea and West Australian samples show more diversity in this context (Fig. 9a, b). There are at most sites (with the exception of the Gulf of California) a well-defined cluster of small specimens with 10 longitudinal costae. It is also evident that loricae with nine longitudinal costae are at all sites on the average larger than those with 10 longitudinal costae. The exception here being a small contingent of very large loricae from West Australia, Sargasso Sea and Gulf of California which have 10 longitudinal costae. A conglomerate analysis of all C. ventricosa data $(n=208)$ from warm water realms is shown graphically in Fig. $10 a$. The small and large 
sized loricae with 10 longitudinal costae are singled out. In between these is a stretched-out cluster formed by loricae with nine longitudinal costae. It is worth noticing that the slope of a line fitting the specimens with nine and 10 longitudinal costae respectively differs slightly. In specimens with 10 longitudinal costae the rate of increase in lorica height (here represented by the distance between the two anterior transverse costae) with increasing anterior transverse costa diameter is less pronounced than in species with nine longitudinal costae.

A dense cluster of small loricae with 10 longitudinal costae (Fig. 10a; box) represents specimens that match the original definition of $C$. ventricosa form ' $A$ '. A further attempt to circumscribe such clusters of specimens is shown in Fig. 10b. While it is beyond dispute possible to single out a peak that size-wise matches the form ' $\mathrm{A}$ ' definition (anterior transverse costa diam. 10-12 $\mu \mathrm{m}$ ), it is also evident that this cluster is immediately followed by a second cluster of specimens where the anterior transverse costa diameter varies from 13-17 $\mu \mathrm{m}$, and in turn by a small peak that represents species that size-wise match the type material of this species. Apart from identifying such size-related trends in our material it is not possible nor recommendable without molecular support to take any further steps with respect to circumscribing further morphospecies forms within the $C$. ventricosa complex. What we see is basically a size-wise continuum yet with three 'peaks' that correspond to $C$. ventricosa sensu stricto, $C$. ventricosa form ' $A$ ' and in between these a third cluster of medium-sized individuals. It is obviously necessary when applying molecular tools in future studies of $C$. ventricosa to carefully link the results to a specific size group and to cautiously register the number of longitudinal costae.

\section{Cosmoeca ventricosa form B (Fig. 11a-i)}

When first described (Thomsen and Boonruang 1984) this form was differentiated from C. ventricosa sensu stricto based only on the presence in 'form B' of anterior spines that are also visible at the light microscopical level. The 'form B' lorica is similar to C. ventricosa only slightly smaller. Our material (Table 2) matches the dimensions of the Thailand 'form B' specimens when comparing the mean values of the two 
datasets. However, it is also obvious that the material examined here does extend the lower end size variability range significantly (Table 2). The number of longitudinal costae is invariably 10 in $C$. ventricosa form B specimens. The region-specific variability in basic lorica dimensions is shown in Fig. 12a. Specimens from the Pacific Ocean and West Australia are markedly larger than those from e.g. the Gulf of California. As commented on and illustrated by Thomsen and Boonruang (1984; loc. cit. Fig. 29) the anterior spines are sharp-pointed anteriorly. In specimens from the Gulf of California (Fig. 11e, f, i) and West Australia the anterior spines are sometimes developed into fairly massive, oblique and sharp-pointed structures (Fig. 12h). Similar but smaller spines are also found on the penultimate layer of longitudinal costal strips (Fig. 11h, arrow). The oblique spines can also be distinguished in the LM (Fig. 11e, f). It should be noticed that specimens with oblique spines all fall within the cluster of small species encircled in Fig. 12a, but also that specimens with standard spines (Fig. 11c, d; Gulf of California) geographically co-occur with specimens with oblique spines (Fig. 11e, f; Gulf of California). Notice that the costal strip pattern as described in the Materials and Methods section is clearly displayed by the specimen illustrated in Fig. 11i (arrow, arrowhead).

\section{Cosmoeca ventricosa form C (Fig. 11j-r; Fig. 13)}

The characteristic features of this form of $C$. ventricosa are modest lorica dimensions and a pronounced reduction in lorica diameter at the level of the middle transverse costa (Thomsen and Boonruang 1984). The material examined here agrees well with the Andaman Sea material (Thomsen and Boonruang 1984) both with respect to the overall appearance of the lorica and dimensional aspects (Table 2). The specimens examined here have invariably 10 longitudinal costae, whereas Thomsen and Boonruang (1984) reports nine or 10 longitudinal costae. There is little both overall and regional variation when scrutinizing selected dimensional parameters (Fig. 12b). There is a fairly consistent relationship between the anterior and middle transverse costa diameters in specimens examined here (Fig. 12c), albeit with some noise in particular in the mid-sized lorica range. In C. ventricosa form C there is typically no anterior spines (Fig. 11l). However, in 
specimens from the Pacific Ocean there may be the occasional lorica with short sharp-pointed and angular anterior spines (Fig. 13a, b). Notice that in particular the empty lorica illustrated in Fig. 13b clearly displays the universal transverse/longitudinal costal strip patterns as elucidated by Leadbeater (2015) and discussed above (Materials and methods section).

\section{Biogeography}

Species of Cosmoeca are widely distributed throughout the global warm water realms (Table 3). While some taxa, i.e. C. norvegica and C. ventricosa (incl. form A) are genuinely cosmopolitan species, others have a so far more restricted known pattern of distribution. In addition to the distribution recorded here (Table 3), C.ceratophora is furthermore observed in samples from the North Pacific Central Gyre (Hoepffner and Haas 1990), Sydney and Darwin, Australia (Tong et al. 1998; Lee et al. 2003), Danish coastal waters (Thomsen et al. 2016) and New Zealand (Moestrup, pers. comm.), C. phuketensis from the East Australian Current, Shark Bay, Sydney and Darwin, Australia (Hallegraeff 1983; Tong 1997b; Tong et al. 1998; Lee et al. 2003), Taiwan (Hara et al. 1997), and New Zealand (Moestrup, pers. comm.), and C. subulata from Japan (Hara and Takahashi, pers. comm.) and the South Atlantic coastal zone, Brazil (Bergesch et al. 2008). The common denominator appears here to be that these three taxa have a distributional preference for warm water habitats, however, with a capacity to also occasionally thrive in temperate waters from both hemispheres.

While the $C$. ventricosa form $A$ tends to be always occurring together with $C$. ventricosa sensu stricto (Thomsen and Boonruang 1984; Thomsen et al. 1990, Thomsen and Østergaard 2017), the form B was observed at all sites with the exception of the Caribbean Sea. Form C was absent from the Gulf of California and the eastern Mediterranean Sea. Form B is additionally recorded from the subarctic North Pacific Ocean (Booth 1990), the Saanich Inlet, Canada (Smith and Hobson 1994), the East Australian Current (Hallegraeff 1983; referred to as Pleurasiga orculaeformis var.), the Beagle Channel, Patagonia (Thomsen, unpublished) and New Zealand (Moestrup, pers. comm.). Form C specimens are also reported from various Arctic sites 
(Thomsen and $\varnothing$ stergaard 2017), and the Beagle Channel, Patagonia (Thomsen, unpublished). The Arctic material of form $\mathrm{C}$ is with reference to lorica dimensions and constructional details convincingly similar to the Andaman Sea material (Thomsen and Boonruang 1984) and material examined here. While the form C has invariably 10 longitudinal costae in the material examined here, the Arctic material (Thomsen and $\emptyset$ stergaard 2017) shows some variability (9-12 longitudinal costae). However, $75 \%$ of all specimens examined had 10 longitudinal costae.

\section{Conclusions}

It appears safe based on the reinvestigation of species of Cosmoeca to conclude that the genus Cosmoeca still comes out as a well-defined and easily applicable genus in a classical morphospecies taxonomical perspective, and further that the individual species (including also the bi-polar C. takahashii which is not treated here) are convincingly circumscribed.

The simultaneous occurrence in the very same sample of distinct size classes of what from a morphological point of view appears to be the same taxon, has been repeatedly reported from a range of species (e.g. Thomsen et al. 1990). It remains unclear whether the occurrence of these differently sized subgroups is biologically or environmentally induced, caused by a combination of these, or perhaps even being separate taxa. For the time being and until actual proof is obtained from the application of molecular tools, it appears relevant to maintain the form $\mathbf{A}$ unity closely attached to $C$. ventricosa sensu stricto.

There are still open questions with reference to the morphotypes identified as forms of $C$. ventricosa. A qualified guess hints at that the spiny form B is likely a separate taxon, perhaps even two taxa distinguished by the presence or absence of oblique-angled spines on longitudinal costal strips.

The form $\mathrm{C}$ has proved morphometrically conservative across vast distances (including the Arctic realms) and is a good additional candidate for becoming an autonomous species.

Form D specimens (Thomsen et al. 1990) are much similar to the form A entity, yet with a distinguishing posterior pedicel comprising a single costal strip. A capable guess is that the form $D$ entity once 
molecularly targeted will disclose similarity to genuine form A specimens and be relegated to an environmentally induced form A morphotype.

Form E specimens have so far been observed only in samples from the Arctic (Thomsen and $\emptyset$ stergaard 2017). It is a well-defined entity with reference to lorica dimensions, overall shape and numerical details (i.e. invariably 12 longitudinal costae, which is an unusual number across the array of species of Cosmoeca) and it is very likely that a future molecular probing will reveal that the form E specimens will prove distant enough from $C$. ventricosa sensu stricto to be described as a separate species.

Because of the spacious and simple lorica construction in species of Cosmoeca, the images first published by Thomsen and Boonruang (1984) were essential in the search for universal patterns in lorica construction and assembly (Leadbeater, pers. comm.). Following the successful technical explanation behind the occurrence of images of Cosmoeca spp. with fundamentally different patterns of symmetry (see Materials and methods section for further details), it is important to emphasize that the basic principles of lorica construction as accounted for by Leadbeater (2015) are now reflected in all images of Cosmoeca spp. available to us.

\section{Author contribution}

Helge A. Thomsen (HAT) has undertaken a major part of the sampling activities and the subsequent microscopical analyses. HAT is further responsible for compiling and writing the paper. Jette B. Østergaard (JBO) has been much involved in the Andaman Sea and the Pacific Ocean sampling. JBO has also carried out the transmission electron microscopical examination of these samples.

\section{Acknowledgements}

Crew and scientists on board the research vessels ('Dana', 'Vaedderen', 'Chakratong Tongyia', 'Malcolm Baldrige') are acknowledged for good collaborative spirit and for providing excellent facilities for collecting 
and processing our samples. Dr. Gunni Ærtebjerg and Steffen Mariager Pedersen are acknowledged for providing the samples from outside the Alexandria Harbour. We are grateful to Dr. Sergio Sanudo-Wilhelmy and Kurt Buck for organizing the trip to Gulf of California. Carol Kosman is warmly acknowledged for her meticulous contribution to this paper. An anonymous reviewer is acknowledged for bringing to our attention the fact that loricae details differ with respect to orientation when comparing micrographs originally presented here and those included in Thomsen and Boonruang (1984). Sincere thanks are due to Dr. Barry Leadbeater (Univ. Birmingham) for providing valuable inputs to those parts of the manuscript that deal with this issue. Main funding sources, i.e. the Independent Research Fund Denmark, the Carlsberg Foundation, Danida (Denmark's development cooperation), the Højgaard Foundation, and the Danish Centre for Marine Research are acknowledged for their generous contributions to our research. The present work was carried out as part of the Galathea3 expedition under the auspices of the Danish Expedition Foundation (Galathea3 contribution P127) and also as part of the Sargasso-Eel 2014 Expedition.

\section{References}

Bergesch, M., Odebrecht, C., Moestrup, Ø., 2008. Loricate choanoflagellates from the South Atlantic coastal zone $\left(\sim 32^{\circ} \mathrm{S}\right)$ including the description of Diplotheca tricyclica sp. nov. Biota Neotrop. 8, 111-122.

Booth, B.C., 1990. Choanoflagellates from the subarctic North Pacific Ocean, with description of two new species. Can. J. Zool. 68, 2393-2402.

Hallegraeff, G.M., 1983. Scale-bearing and loricate nanoplankton from the East Australian Current. Bot. Mar. 26, 493-515.

Hara, S., Sheu, J., Chen, Y.L., Takahashi, E., 1997. Choanoflagellates (Sarcomastigophora, Protozoa) from the coastal waters of Taiwan and Japan (II): Species composition and biogeography. Zool. Stud. 36, 98-110. 
Hoepffner, H., Haas, L.W., 1990. Electron microscopy of nanoplankton from the North Pacific central gyre. J. Phycol. 26, 421-439.

Leadbeater, B.S.C., 1973. External morphology of some marine choanoflagellates from the coast of Jugoslavia. Arch. Protistenk. 115, 234-252.

Leadbeater, B.S.C., 2015. The Choanoflagellates: Evolution, biology and ecology. Cambridge University Press.

Lee, W.J., Brandt, S.M., Vørs, N., Patterson, D.J., 2003. Darwin's heterotrophic flagellates. Ophelia 57, 6398.

Manton, I., Bremer, G., 1981. Observations on lorica structure and aspects of replication in the Pleurasiga sphyrelata Thomsen complex (= Polyfibula spp., gen. n.) (Choanoflagellata). Zool. Scr. 10, 273-291.

Menezes, S., 2005. Nanoplankton biodiversity in the Pettaquamscutt river estuary, Rhode Island, U.S.A. PhD thesis, Univ. Rhode Island, 319pp.

Moestrup, $\varnothing ., 1979$. Identification by electron microscopy of marine nanoplankton from New Zealand, including the description of four new species. New Zeal. J. Bot. 17, 61-95.

Moestrup, Ø., Thomsen, H.A., 1980. Preparation of shadow-cast whole mounts. In: Gantt, E. (Ed.), Handbook of Phycological methods. Vol. III. pp. 385-390 (Cambridge).

Nitsche, F., Thomsen, H.A., Richter, D.J., 2017. Bridging the gap between morphological species and molecular barcodes - exemplified by loricate choanoflagellates. Europ. J. Protistol. 57, 26-37.

Schiller, J., 1925. Die planktonischen Vegetationen des Adriatischen Meeres. B. Chrysomonadina, Heterokontae, Cryptomonadina, Eugleninae, Volvocales. I. Systematischer Teil. Arch. Protistenk. 53, 59123.

Smith, P.J., Hobson, L.A., 1994. Temporal variations in the taxonomic composition of flagellated nanoplankton in a temperate fjord. J. Phycol. 30, 369-375.

Takahashi, E., 1981. Loricate and scale-bearing protists from Lützow-Holm Bay, Antarctica I. Species of the Acanthoecidae and the Centrohelida found at a site selected on the fast ice. Antarctic Record 73, 1-22. 
Thomsen, H.A., 1976. Studies on marine choanoflagellates II. Fine- structural observations on some silicified choanoflagellates from the Isefjord (Denmark), including the description of two new species. Norw. J. Bot. 23, 33-51.

Thomsen, H.A., 1982. Planktonic choanoflagellates from Disko Bugt, West Greenland, with a survey of the marine nanoplankton of the area. Meddr. Grønland, Bioscience 8, 1-35.

Thomsen, H.A., Boonruang, P., 1984. A light and electron microscopical investigation of loricate choanoflagellates (Acanthoecidae, Choanoflagellida) from the Andaman Sea, SW Thailand: Species of Cosmoeca gen.n. Zool. Scripta 13, 165-181.

Thomsen, H.A., Buck, K R., 1991. Choanoflagellate diversity with particular emphasis on the Acanthoecidae. In: Patterson, D.J., Larsen, J. (Eds.), Free-living heterotrophic flagellates. Clarendon Press, Oxford, pp. 259-284.

Thomsen, H.A., Østergaard, J.B., 2017. Acanthoecid choanoflagellates from the Atlantic Arctic region - a baseline study. Heliyon 3 (2017) e00345 doi: 10.1016/j.heliyon.2017. e00345

Thomsen, H.A., Østergaard, J.B., 2019a. Loricate choanoflagellates (Acanthoecida) from warm water seas. I. Conioeca gen. nov. and Nannoeca Thomsen. Europ. J. Protistol. 67, 77-88.

Thomsen, H.A., Østergaard, J.B., 2019b. Loricate choanoflagellates (Acanthoecida) from warm water seas. II. Bicosta, Apheloecion, Campyloacantha and Saroeca. Europ. J. Protistol. 67, 114-131.

Thomsen, H.A., Østergaard, J.B., 2019c. Loricate choanoflagellates (Acanthoecida) from warm water seas. III. Acanthocorbis Hara and Takahashi and Stephanoeca Ellis. Europ. J. Protistol. 69, 52-69.

Thomsen, H.A., Buck, K.R., Chavez, F.P., 1991. Choanoflagellates of the central California waters: Taxonomy, morphology and species assemblages. Ophelia 33, 131-164.

Thomsen, H.A., Buck, K.R., Coale, S.L., Garrison, D.L., Gowing, M.M., 1990. Loricate choanoflagellates (Acanthoecidae, Choanoflagellida) from the Weddell Sea, Antarctica. Zool. Scr. 19, 367-387.

Thomsen, H.A., Nitsche, F., Richter, D.J., 2016. Seasonal occurrence of loricate choanoflagellates in Danish inner waters. Protist 167, 622-638. 
Throndsen, J., 1974. Planktonic choanoflagellates from North Atlantic Waters. Sarsia 56, 95-122.

Tong, S.M., 1997a. Choanoflagellates in Southampton Water including the description of three new species. J. Mar. Biol. Assoc. U.K. 77, 929-958.

Tong, S.M., 1997b. Heterotrophic flagellates from the water column in Shark Bay, Western Australia. Mar. Biol. 128, 517-536.

Tong, S.M., Nygaard, K., Bernard, C., Vørs, N., Patterson, D.J., 1998. Heterotrophic flagellates from the water column in Port Jackson, Sydney, Australia. Europ. J. Protistol. 34, 162-194. 


\section{Legends:}

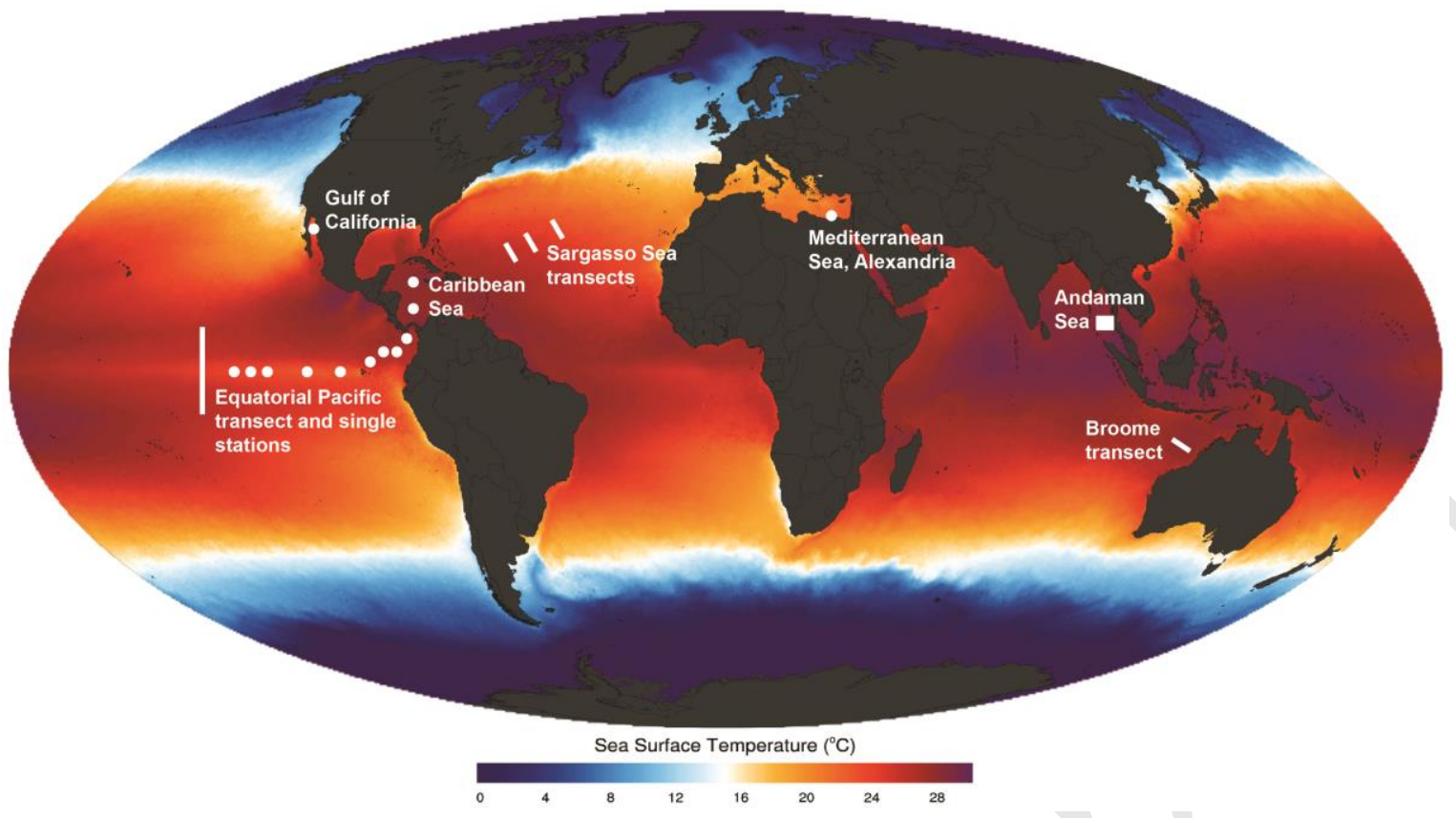

Fig. 1. Map showing the approximate sampling sites for material reported here and MODIS sea surface temperatures (2003-2011 average). A circle refers to a single spot sampling, while a line or square indicates that samples were collected along extended transects (for further information see the materials and methods section in Thomsen and Østergaard (2019a)). 


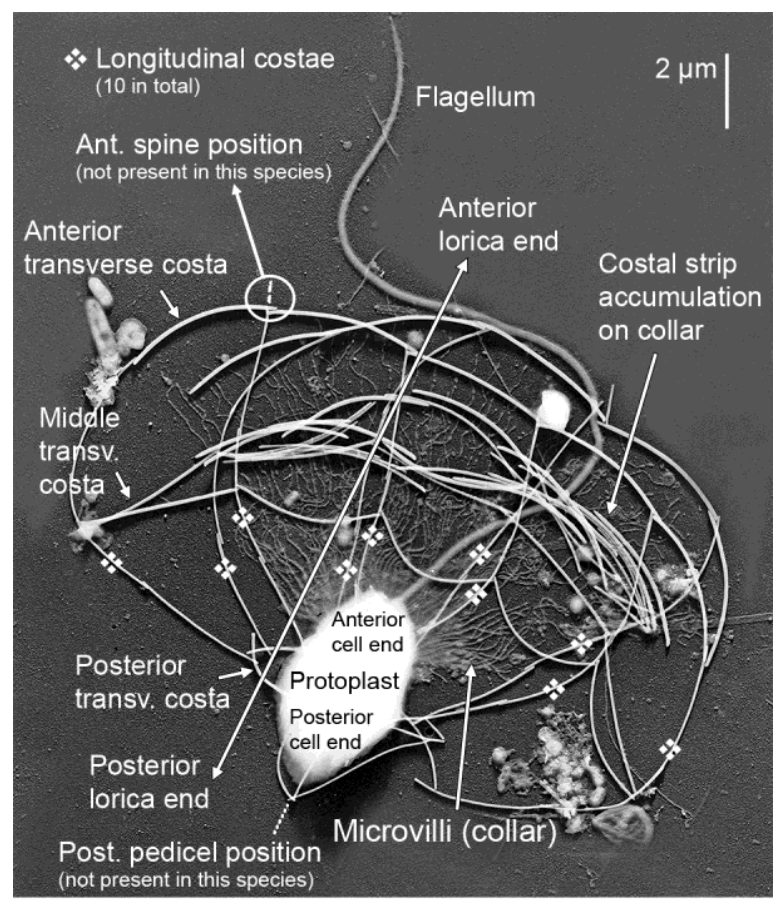

Fig. 2. Cosmoeca norvegica TEM whole mount labelled to introduce loricate choanoflagellate terminology. 

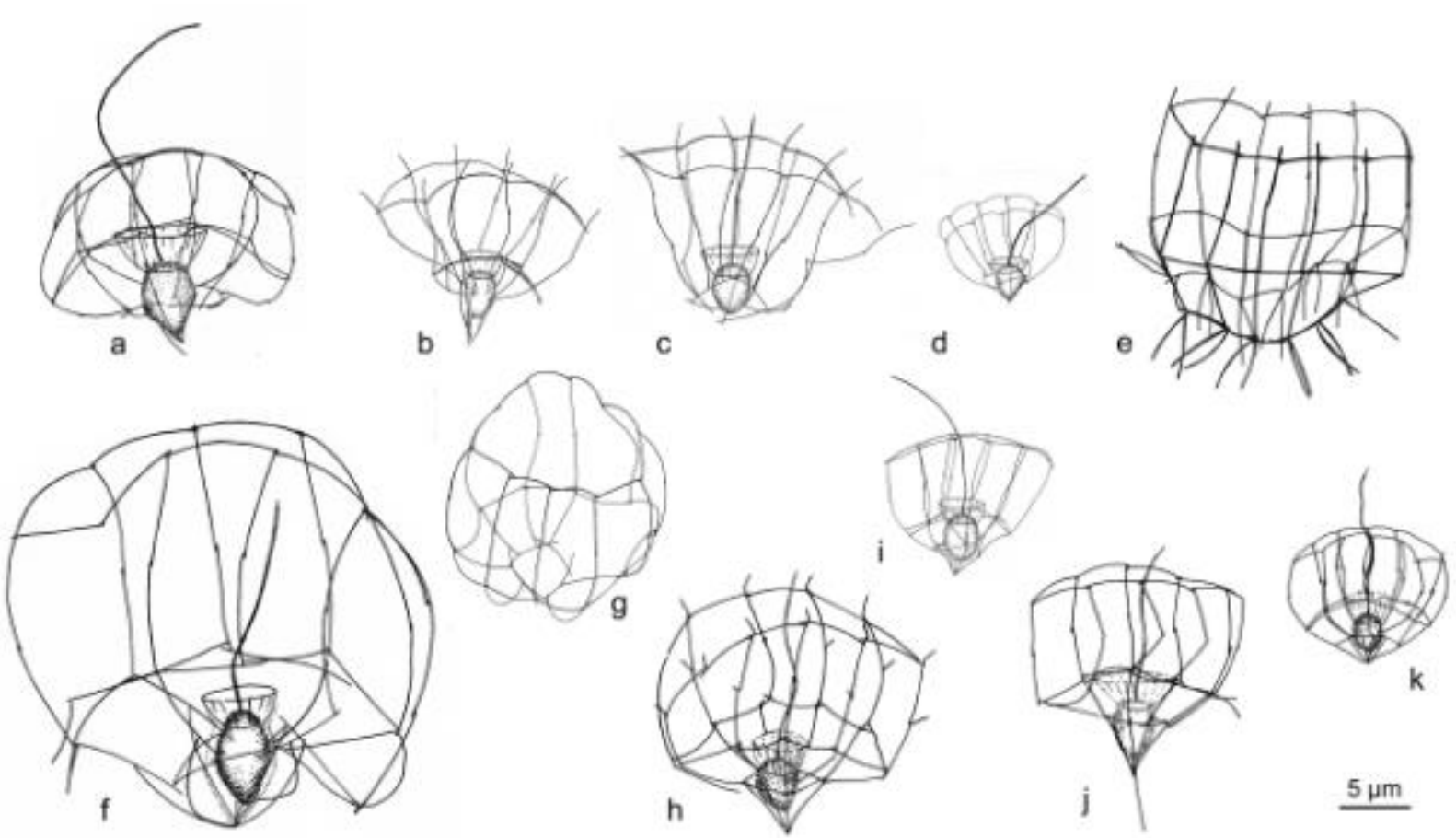

Fig. 3. Drawings of Cosmoeca spp. reproduced to approximately the same scale. (a) C. norvegica; (b) C. subulata; (c) C. ceratophora; (d) C. phuketensis; (e) C. takahashii; (f) C. ventricosa; (g) C. ventricosa form A; (h) C. ventricosa form B; (i) C. ventricosa form C; (j) C. ventricosa form D; (k) C. ventricosa form E. 


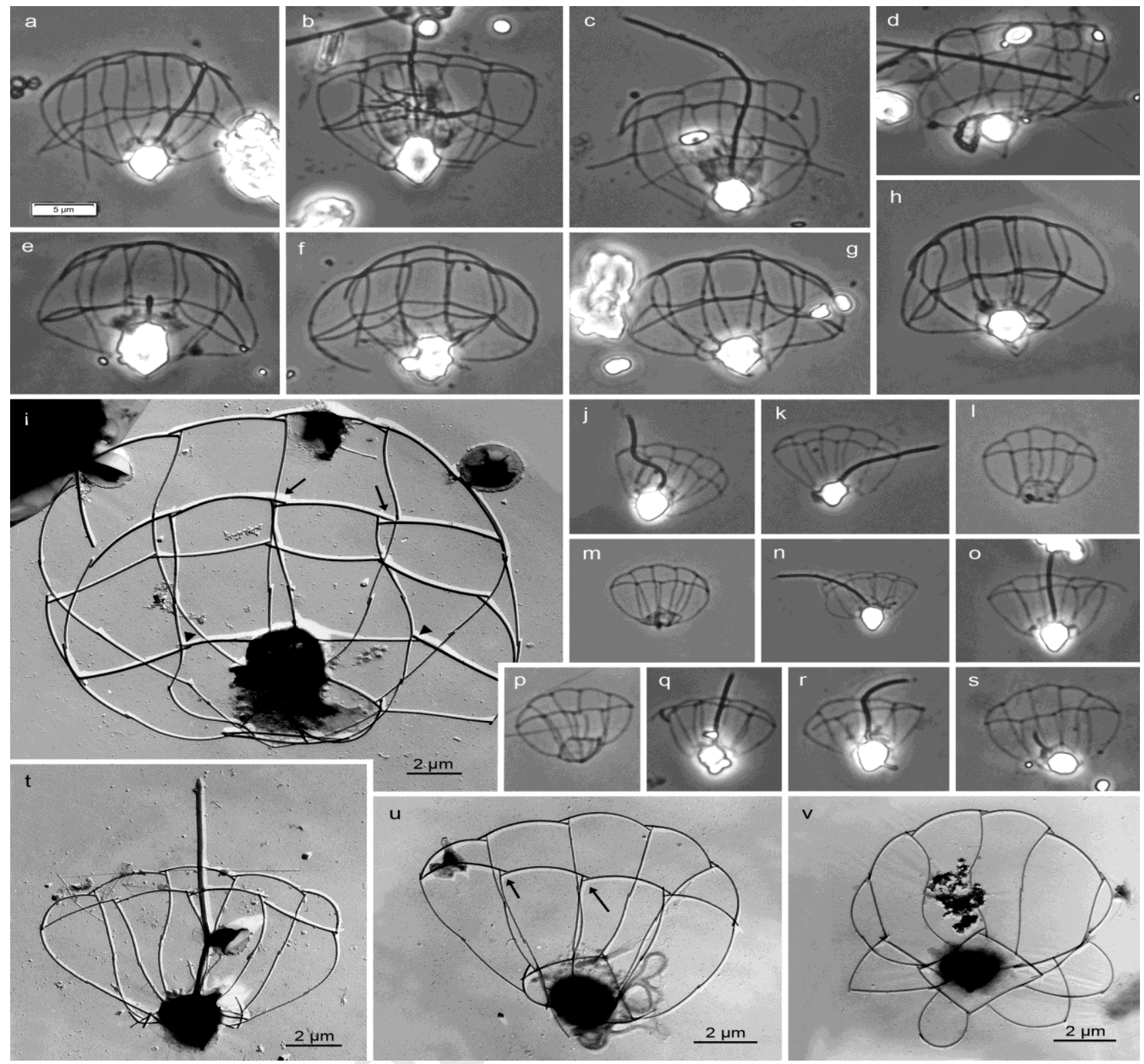

Fig. 4. Cosmoeca norvegica (a-i) and C. phuketensis (j-v) LM (a-h, j-s; phase contrast) and TEM whole mounts (i, t-v) from West Australia (a-c, j-n), the Sargasso Sea (d), the Pacific Ocean (e, i, r-v), the Gulf of California (f, g), and the Caribbean Sea (h, o-q). (a-i) Cells showing the conservative appearance of the $C$. norvegica lorica around the globe; arrows and arrowheads (i) point to costal strip connections as viewed from the outside of the lorica (see text for further explanation); (j-s) Selection of $C$. phuketensis LM images to show the size variability encountered; (t-v) Lorica details exemplified from three Pacific Ocean specimens; arrows (u) point to costal strip connections as viewed from the outside of the lorica (see text for further explanation). The scalebar (a) applies to all LM micrographs. 

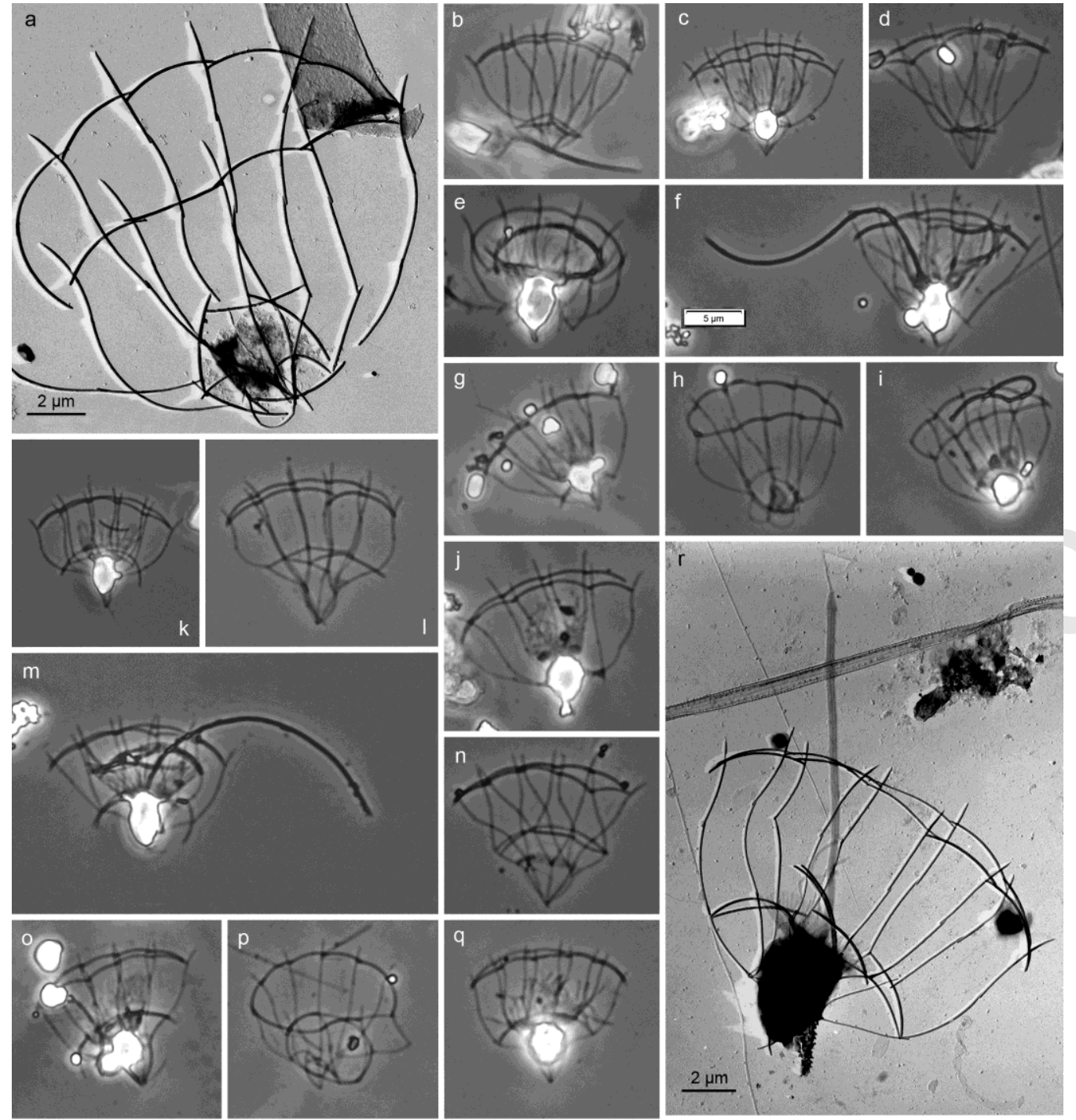

Fig. 5. Cosmoeca ceratophora (a-j) and C. subulata (k-r) LM (b-q; phase contrast) and TEM whole mounts $(a, r)$ from the Gulf of California $(a, b, e, g)$, West Australia (c, d, f, k-n), the Pacific Ocean (g, o-q), the Sargasso Sea ( $h$ ), the Caribbean Sea (i), and the Andaman Sea ( $r)$. (a-j) Cells showing the conservative appearance of the $C$. ceratophora lorica from around the globe; (k-r) Selection of $C$. subulata images to show the size variability encountered. The scalebar (f) applies to all LM micrographs. 

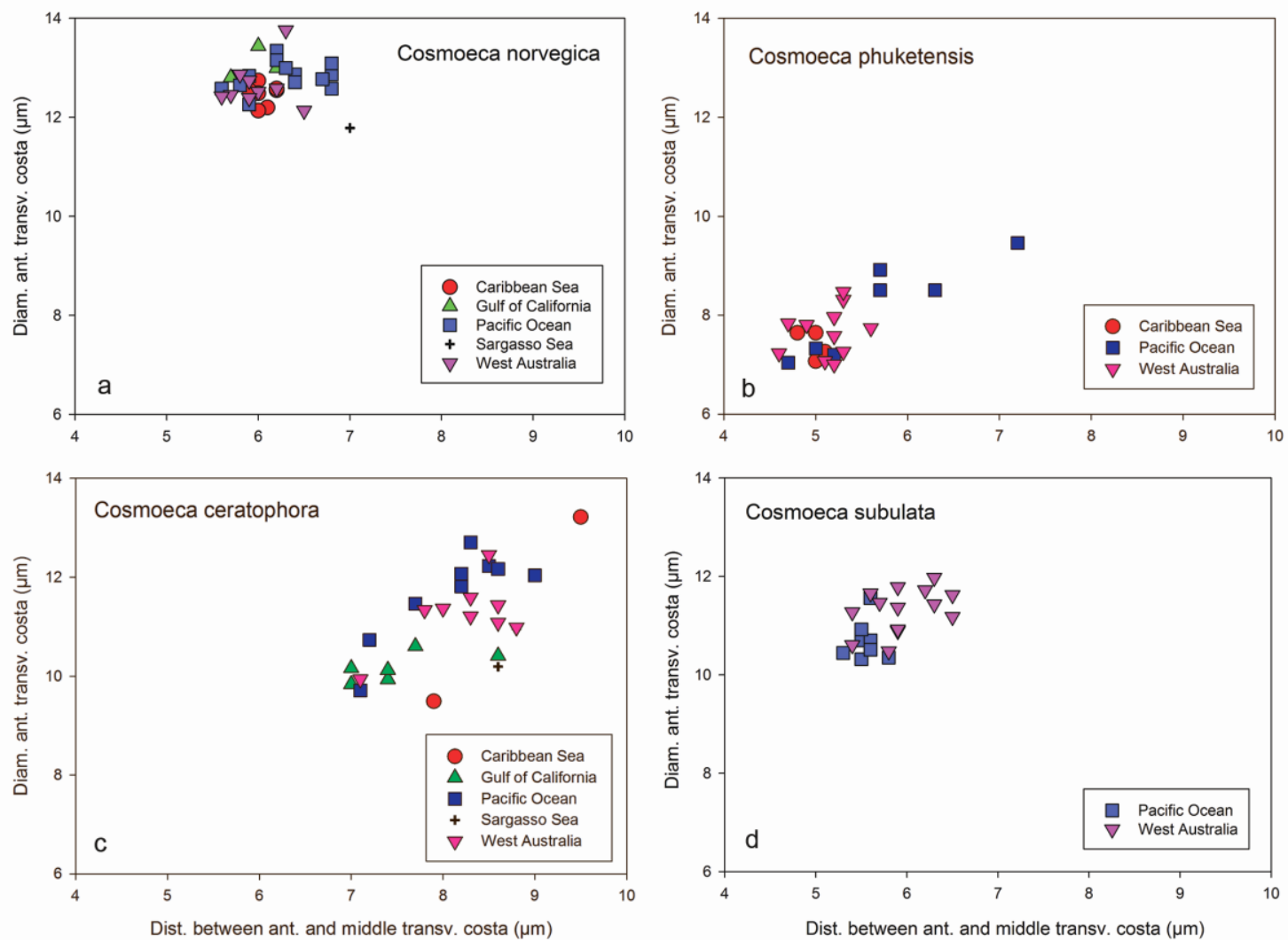

Fig. 6. Diagrams displaying the size variability encountered in Cosmoeca norvegica (a), C. phuketensis (b), C. ceratophora (c) and C. subulata (d) when plotted as connected values of distance between the two anteriormost transverse costae (x-axis), and the anterior transverse costa diameter (y-axis). Notice that $C$. norvegica is the least variable species closely followed by $C$. subulata. 

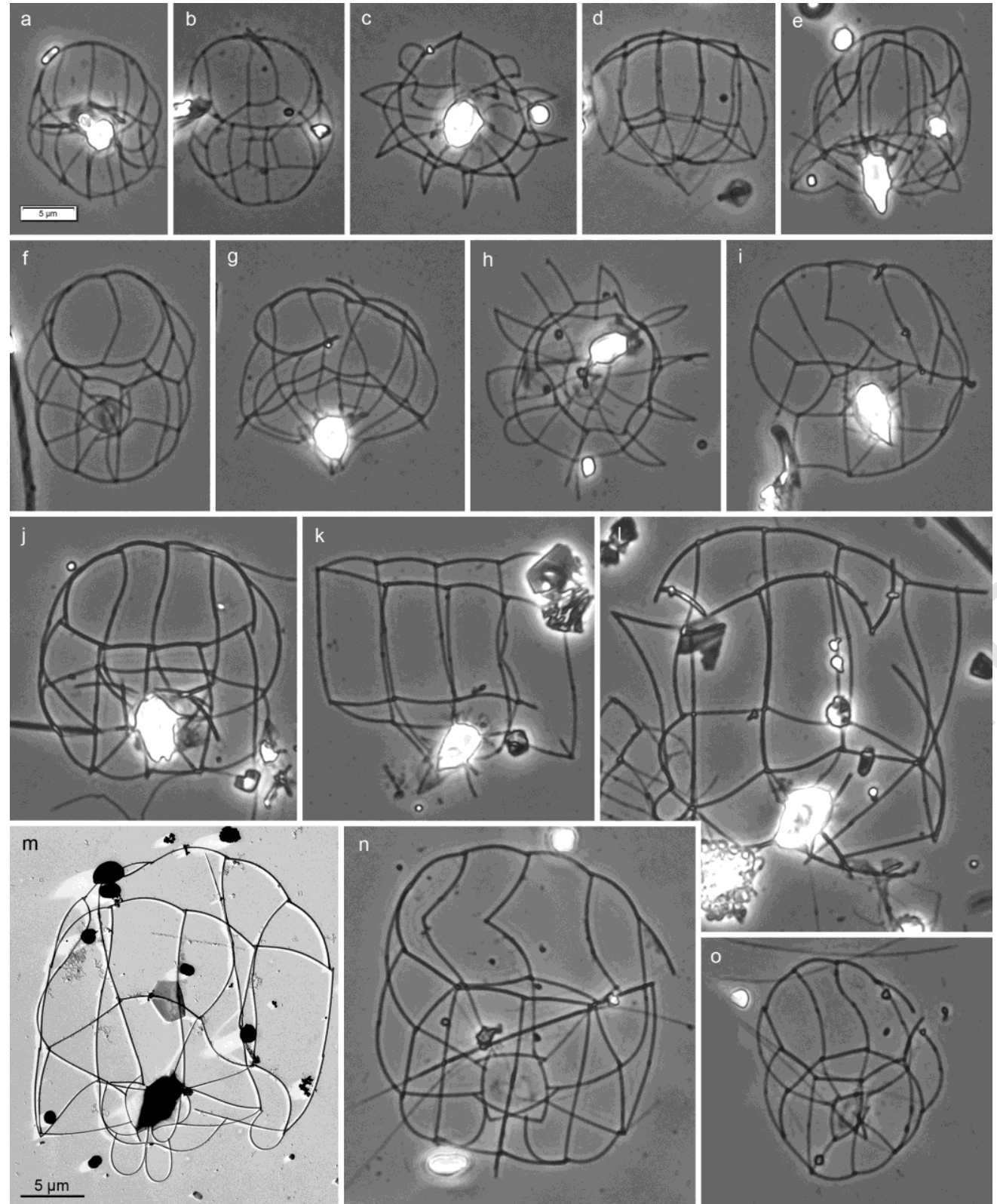

Fig. 7. Cosmoeca ventricosa LM (a-I, $n$, o; phase contrast) and TEM (m) whole mounts from West Australia

(a-I) and the Gulf of California (m-o). (a-I) Specimens from West Australia organized to show size variability;

specimens illustrated in a-e correspond to $C$. ventricosa form $A ;(m, n)$ Same size Gulf of California specimens illustrated from TEM and LM; (o) Form ' $A$ ' specimen. The scalebar (a) applies to all LM micrographs. 


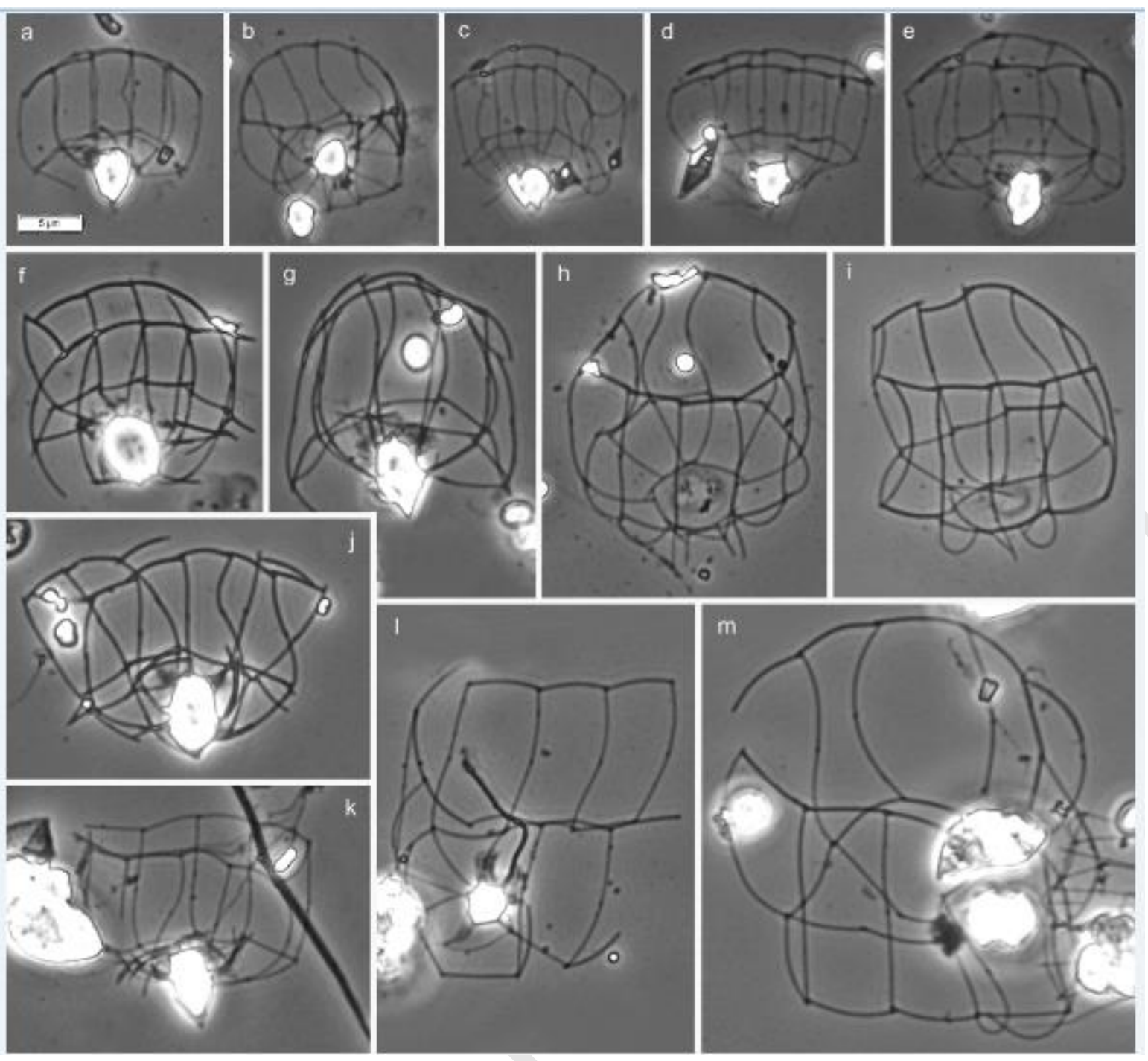

Fig. 8. Cosmoeca ventricosa LM whole mounts from the Sargasso Sea; (a-m) selection of specimens

organized to immediately reveal the morphological variability encountered; specimens illustrated in a-d correspond to C. ventricosa form A. The scalebar (a) applies to all LM micrographs. 

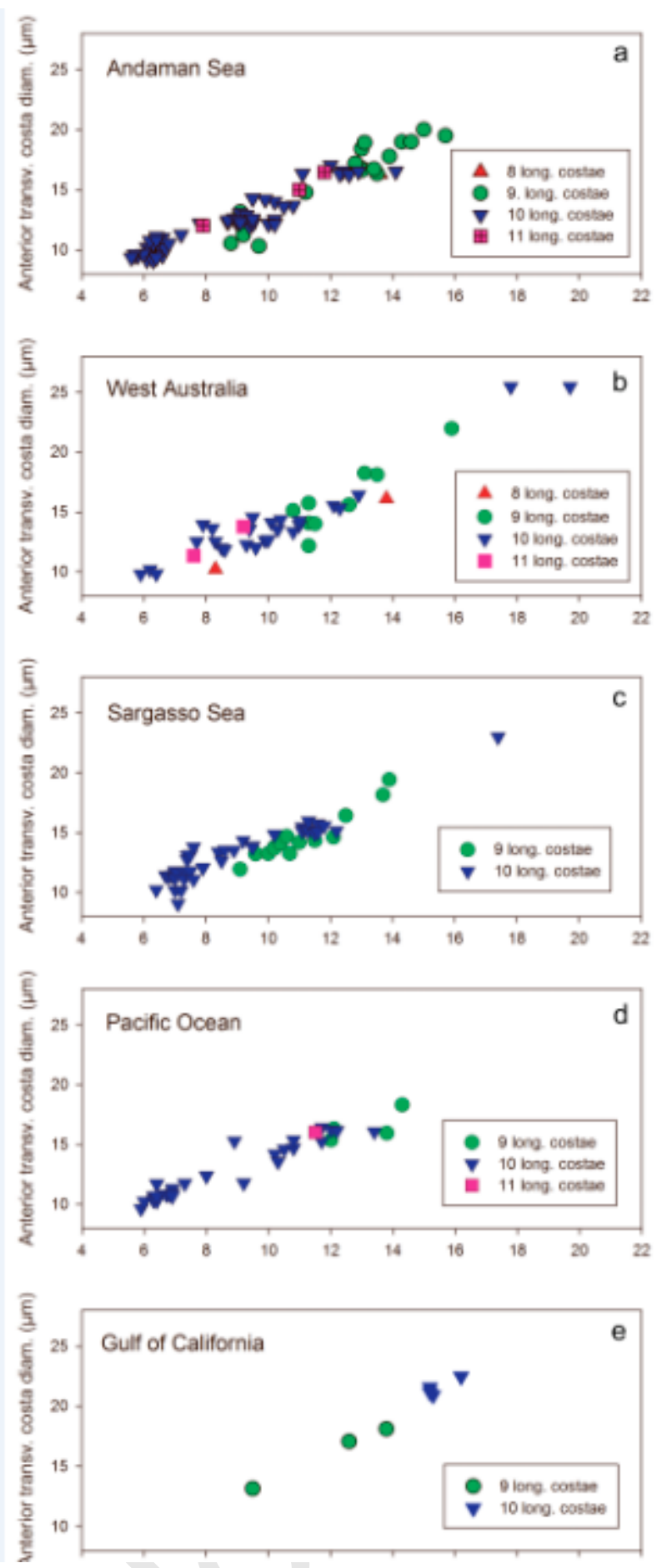

Fig. 9. Diagrams (a-e) illustrating the $C$. ventricosa site-specific relationship between lorica size (x-axis: distance between anterior and middle transverse costa / y-axis: anterior transverse costa diameter) and number of longitudinal costae. 


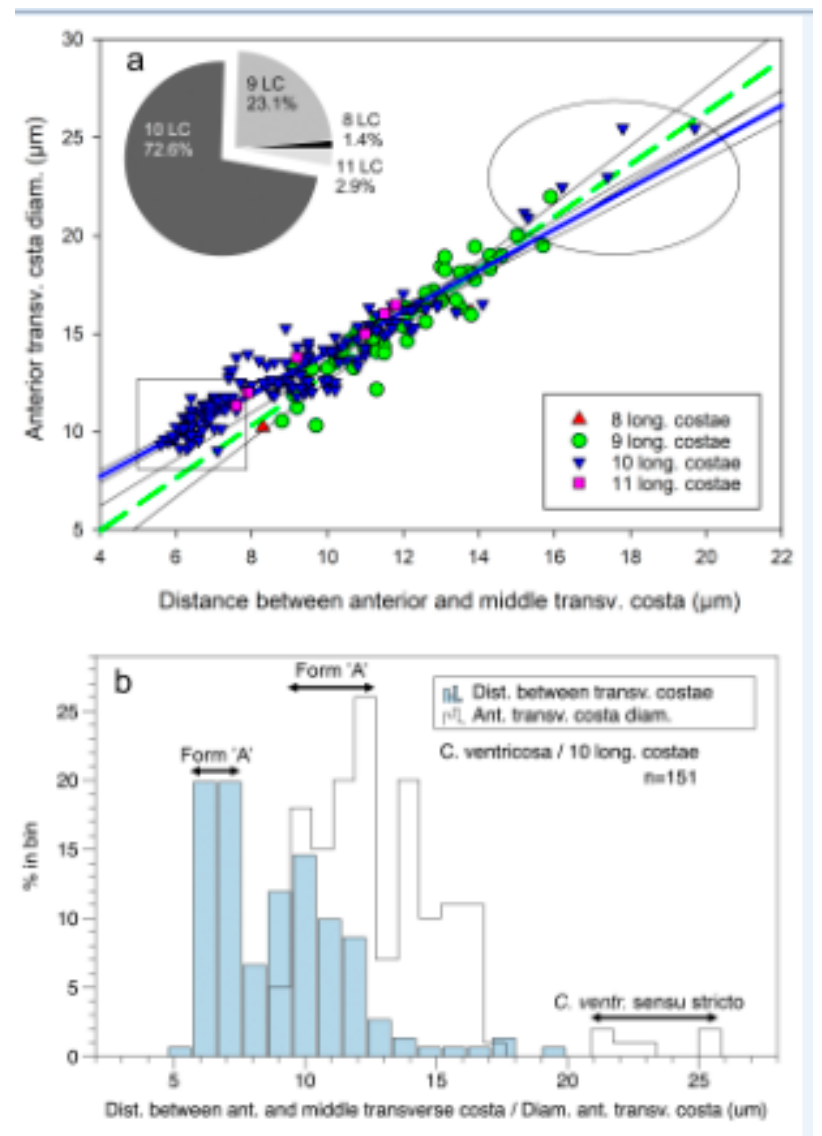

Fig. 10. (a) Cosmoeca ventricosa composite diagram $(n=208)$ displaying the relationship between lorica dimensions and the number of longitudinal costae. The oval demarcates a cluster of large-size loricae with 10 longitudinal costae. The square marks off specimens with 10 longitudinal costae that match the $C$. ventricosa 'form A' definition. Regression lines and $95 \%$ confidence intervals are included for specimens with $9\left(r^{2}=0.872\right.$; green dashed line $)$ and $10\left(r^{2}=0.898\right.$; blue solid line) longitudinal costae respectively. Notice that the trend-line for loricae with 9 longitudinal costae is slightly more steeply inclined. The piediagram (inset) shows the percentage composition of loricae with any specific number of longitudinal costae; (b) Binned histogram illustrating a weakly defined bimodal size distribution in C. ventricosa specimens with 10 longitudinal costae (material from the Andaman Sea / $n=151$ ). The 'form A' peaks and also the $C$. ventricosa sensu stricto peak are marked off. 


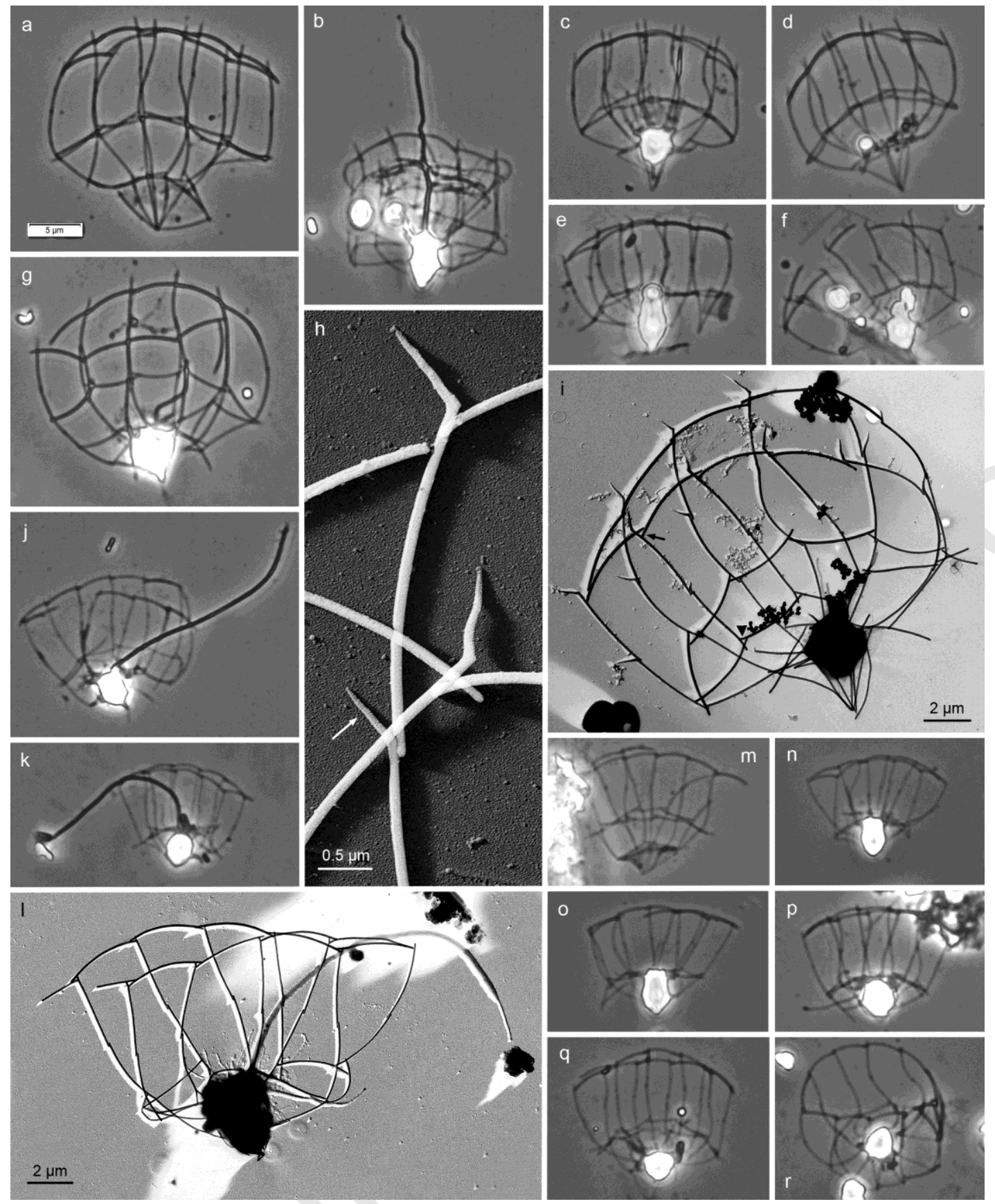

Fig. 11. Cosmoeca ventricosa form ' $B$ ' (a-i) and C. ventricosa form ' $C$ ' (j-r) LM (a-g, j, k, m-r; phase contrast) and TEM (h, i, l) whole mounts from West Australia $(a, g, m-o)$, the Sargasso Sea $(b, j, q, r)$, the Gulf of California (c-f, h, i), the Pacific Ocean (k), the Andaman Sea (I), and the Caribbean Sea (p). (a-g) Selection of C. ventricosa form ' $B$ ' images to show the variability encountered; (h) Detail of longitudinal costal strip spines (reverse printing); the arrow points to a spine on a second from the top longitudinal costal strip (i) Complete specimen; notice that less developed spines are also found at the anterior tip of the second layer 
of longitudinal costal strips; costal strip interconnections clearly displaying basic principles are pointed out (arrow and arrowhead) $(\mathbf{j}, \mathbf{k}, \mathbf{m}-\mathbf{r})$ Selection of $C$. ventricosa form ' $C$ ' specimens; notice $(j, k)$ the very long flagella; (I) Complete cell. The scalebar (a) applies to all LM micrographs.
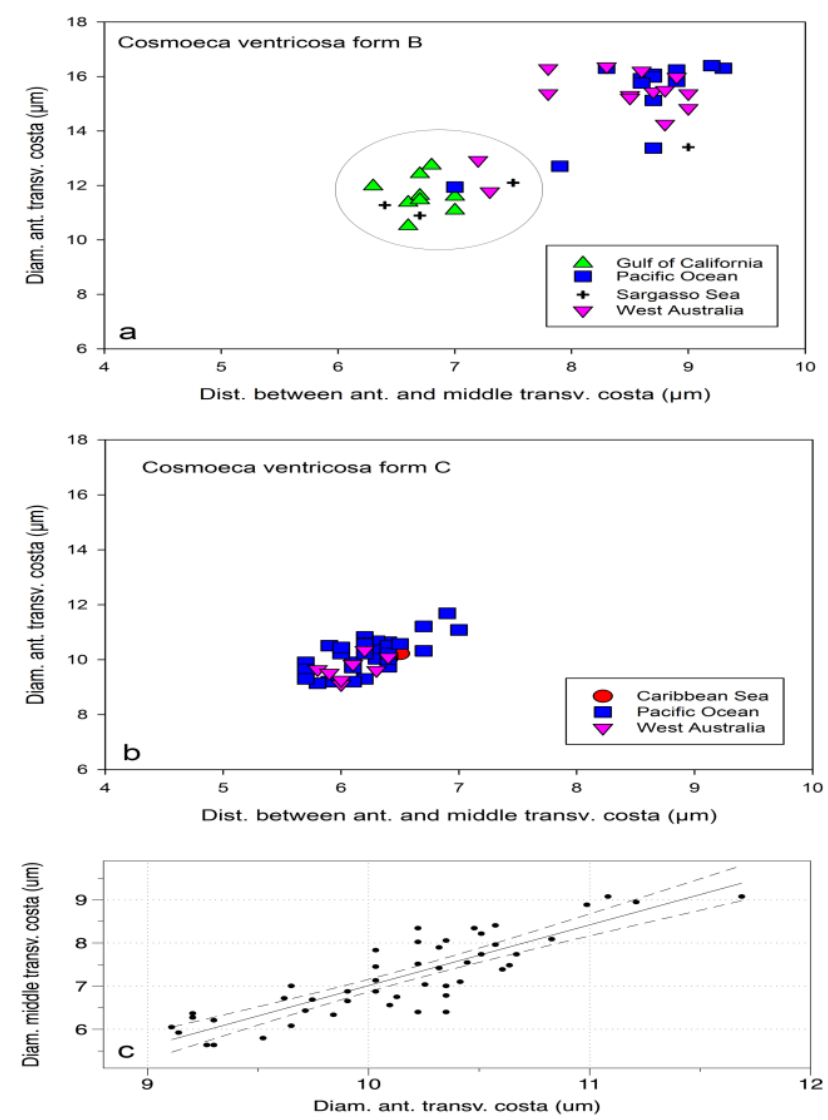

Fig. 12. (a, b) Diagrams illustrating the size variability encountered in $C$. ventricosa form $B(a)$ and $C$. ventricosa form $\mathrm{C}(\mathrm{b})$; the specimens encircled (a) comprise amongst others all individuals with hooked longitudinal costal strip spines; (c) Plot and trendline $\left(r^{2}=0.74\right)$ illustrating the $C$. ventricosa form $C$ size relationship between anterior and middle transverse costa diameter. The dashed lines are the 95\% confidence intervals. 

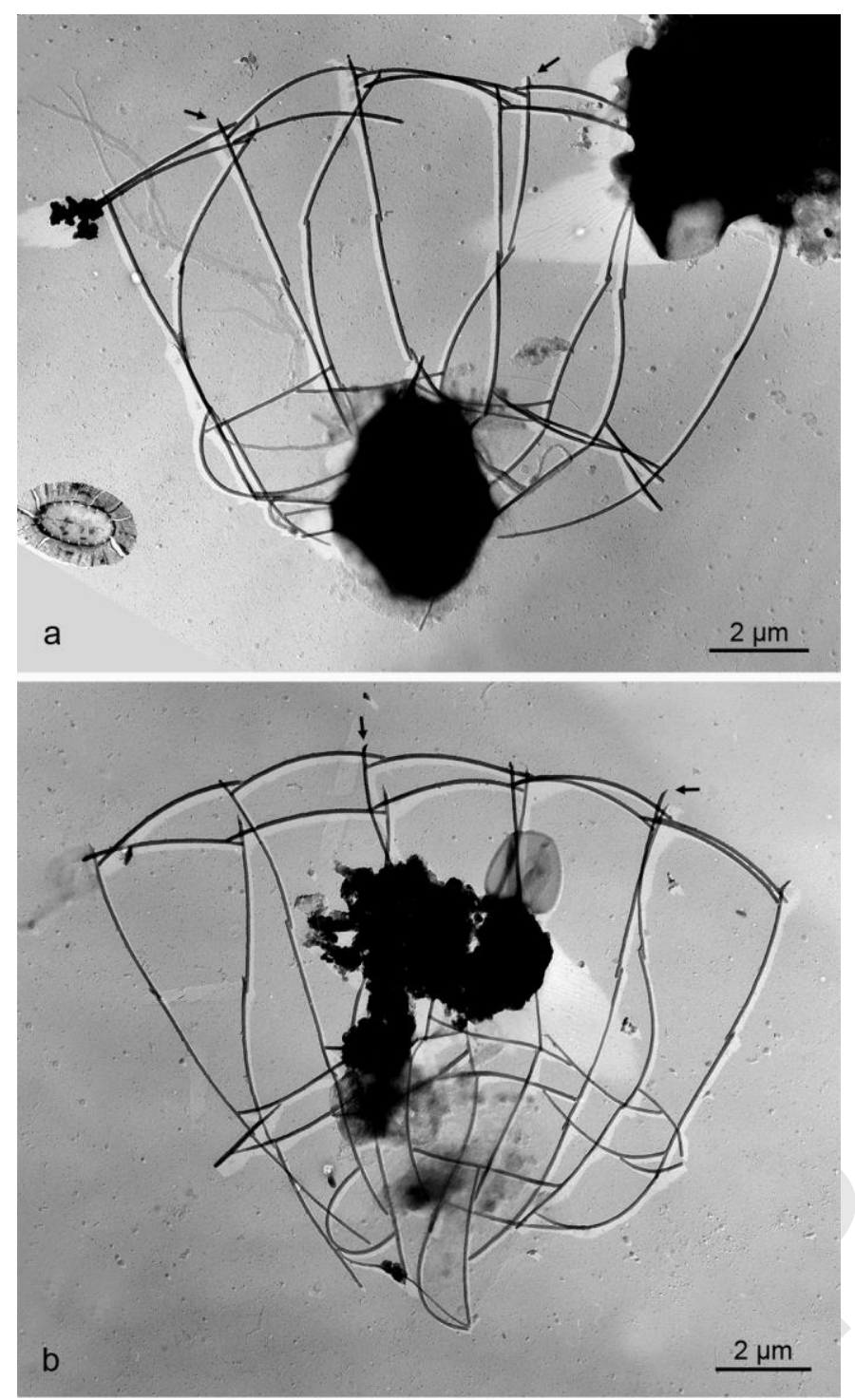

Fig. 13. Cosmoeca ventricosa form ' $C$ ' TEM whole mounts from the Pacific Ocean. Notice that there are in both micrographs tiny anterior spines (with obliquely cut off tips) that terminate the lorica anteriorly (arrows). 
Table 1: Lorica dimensions $(\mu \mathrm{m})$ in four Cosmoeca species collected from warm water habitats. Numbers in bracket are extracted from the type descriptions (Thomsen and Boonruang 1984).

\begin{tabular}{|c|c|c|c|c|c|c|c|}
\hline Species & & 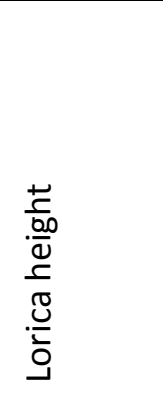 & 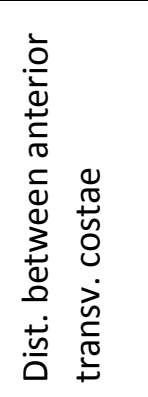 & 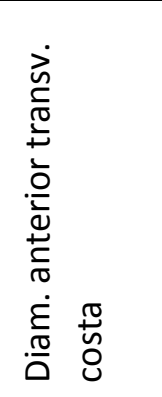 & 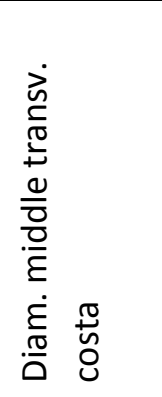 & 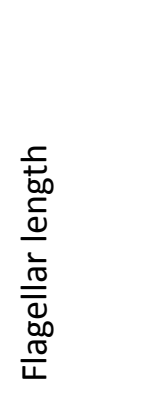 & 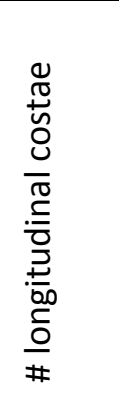 \\
\hline \multirow[t]{3}{*}{ Cosmoeca norvegica } & Mean \pm SD & $\begin{array}{l}14.8 \pm 0.7 \\
(12.5)\end{array}$ & $6.2 \pm 0.4$ & $12.7 \pm 0.4$ & $12.8 \pm 0.6$ & & $\begin{array}{l}10 \\
(10)\end{array}$ \\
\hline & Range & $13.6-16.2$ & $5.6-7.0$ & $\begin{array}{l}11.8-13.8 \\
(10-12)\end{array}$ & $\begin{array}{l}11.1-13.9 \\
(10-12)\end{array}$ & & \\
\hline & $\mathrm{n}$ & 32 & 34 & 34 & 34 & & 34 \\
\hline \multirow[t]{3}{*}{ Cosmoeca phuketensis } & Mean \pm SD & $\begin{array}{l}8.0 \pm 0.6 \\
(8.0)\end{array}$ & $5.3 \pm 0.6$ & $\begin{array}{l}7.7 \pm 0.7 \\
(6.4)\end{array}$ & $\begin{array}{l}3.3 \pm 0.3 \\
(2.3)\end{array}$ & $9.6 \pm 1.7$ & $\begin{array}{l}9 \\
\text { (9) }\end{array}$ \\
\hline & Range & $\begin{array}{l}7.2-9.9 \\
(7-8.5)\end{array}$ & $4.6-7.2$ & $\begin{array}{l}7.0-9.5 \\
(5.5-7.2)\end{array}$ & $\begin{array}{l}3.0-3.6 \\
(1.9-3.2)\end{array}$ & $7.9-12.5$ & \\
\hline & $\mathrm{n}$ & 23 & 23 & 23 & 5 & 11 & 23 \\
\hline \multirow[t]{3}{*}{ Cosmoeca ceratophora } & Mean \pm SD & $\begin{array}{l}12.8 \pm 1.0 \\
(14.4)\end{array}$ & $8.1 \pm 0.7$ & $\begin{array}{l}11.1 \pm 1.0 \\
(10.7)\end{array}$ & $\begin{array}{l}4.2 \pm 0.7 \\
(4.2)\end{array}$ & $19.8 \pm 8.7$ & $\begin{array}{l}10 \\
(10)\end{array}$ \\
\hline & Range & $\begin{array}{l}10.7-14.8 \\
(12.5-15)\end{array}$ & $7.0-9.5$ & $\begin{array}{l}9.5-13.2 \\
(9.3-12.7)\end{array}$ & $\begin{array}{l}3.4-5.3 \\
(3.5-5)\end{array}$ & $10-26.8$ & \\
\hline & $\Omega_{0}$ & 28 & 28 & 28 & 6 & 3 & 28 \\
\hline \multirow[t]{3}{*}{ Cosmoeca subulata } & Mean \pm SD & $\begin{array}{l}13.1 \pm 0.8 \\
(13.4)\end{array}$ & $5.8 \pm 0.4$ & $\begin{array}{l}11.1 \pm 0.5 \\
(10.1)\end{array}$ & $\begin{array}{l}7.1 \pm 0.4 \\
\text { (7) }\end{array}$ & $19.7 \pm 9.2$ & \\
\hline & Range & $\begin{array}{l}11.8-14.7 \\
(12-15)\end{array}$ & $5.3-6.5$ & $\begin{array}{l}10.3-12 \\
(9.2-11.8)\end{array}$ & $\begin{array}{l}6.1-7.8 \\
(5.7-8)\end{array}$ & $9.8-28.1$ & $\begin{array}{l}\text { 10-(11) } \\
\text { (10) }\end{array}$ \\
\hline & $\mathrm{n}$ & 23 & 23 & 23 & 23 & 3 & 23 \\
\hline
\end{tabular}


Table 2. Lorica dimensions ( $\mu \mathrm{m})$ of $C$. ventricosa form B and $C$. ventricosa form C. Numbers in brackets are from Thomsen and Boonruang (1984).

\begin{tabular}{|l|l|l|l|l|l|l|l|}
\hline Taxon & & $\begin{array}{l}\text { Lorica } \\
\text { height }\end{array}$ & $\begin{array}{l}\text { Dist. } \\
\text { between } \\
\text { ant. trans. } \\
\text { costae }\end{array}$ & $\begin{array}{l}\text { Diam. ant. } \\
\text { transv. } \\
\text { costa }\end{array}$ & $\begin{array}{l}\text { Diam } \\
\text { middle } \\
\text { trans. } \\
\text { costa }\end{array}$ & $\begin{array}{l}\text { Diam. } \\
\text { post. } \\
\text { transv. } \\
\text { costa }\end{array}$ & $\begin{array}{l}\text { Flagellar } \\
\text { length }\end{array}$ \\
\hline $\begin{array}{l}\text { C. ventricosa } \\
\text { form B }\end{array}$ & $\mathrm{n}$ & 33 & 40 & 40 & 34 & 7 & 5 \\
\cline { 2 - 8 } & Mean & $\begin{array}{l}17.1 \\
(18.0)\end{array}$ & 8 & 14.1 & 13.3 & 6.5 & 16.6 \\
\cline { 2 - 8 } & SD & 2.39 & 0.96 & 2.00 & 2.25 & 1.18 & 5.85 \\
\cline { 2 - 8 } & Range & $12.9-21.0$ & $6.3-9.3$ & $10.5-16.4$ & $9.5-16.0$ & $3.8-7.7$ & $8.5-21.5$ \\
& $(16-20)$ & & $(12.7-15.9)$ & $(11.1-14.6)$ & & \\
\hline $\begin{array}{l}\text { C. ventricosa } \\
\text { form C }\end{array}$ & $\mathrm{n}$ & 44 & 48 & 48 & 48 & 5 & 3 \\
\cline { 2 - 8 } & Mean & 11.8 & 6.3 & 10.1 & 7.2 & 3.9 & 20.3 \\
& $(10.4)$ & & $(8.3)$ & $(6.3)$ & & $17.7-24.2$ \\
\cline { 2 - 8 } & SD & 1.04 & 0.32 & 0.57 & 0.93 & 0.44 & 3.42 \\
\cline { 2 - 8 } & Range & $9.6-14.1$ & $5.7-7.2$ & $9.1-11.7$ & $5.6-9.1$ & $3.2-4.3$ & \\
\hline
\end{tabular}


Table 3. Occurrence pattern of species discussed here and in Thomsen and $\emptyset$ stergaard (2019a-c). New species described in Thomsen and Østergaard (2019a-c) are marked with *.

\begin{tabular}{|c|c|c|c|c|c|c|c|}
\hline Taxon or Species & 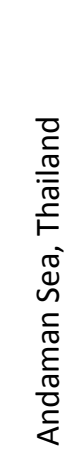 & 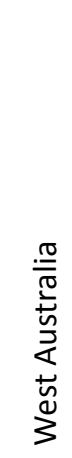 & 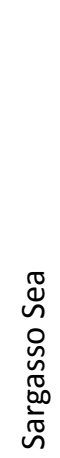 & 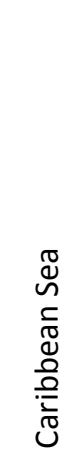 & 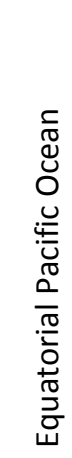 & 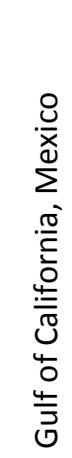 & 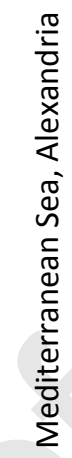 \\
\hline Acanthocorbis apoda & $x$ & & & & & & 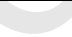 \\
\hline A. camarensis & $x$ & & & & & & \\
\hline A. campanula & $x$ & $\mathrm{x}$ & $x$ & & & & \\
\hline A. conicella* & & $\mathrm{x}$ & $\mathrm{x}$ & & & $\mathrm{x}$ & $\mathrm{x}$ \\
\hline A. gladiella* & $\mathrm{x}$ & $\mathrm{x}$ & $\mathrm{x}$ & $\mathrm{x}$ & $\mathrm{x}$ & & \\
\hline A. haurakiana & $\mathrm{x}$ & $\mathrm{x}$ & $\mathrm{x}$ & & & & \\
\hline Apheloecion articulatum & $\mathrm{x}$ & $\mathrm{x}$ & 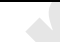 & $x^{2}$ & & & $\mathrm{x}$ \\
\hline A. eqpacia* & $\mathrm{x}$ & $\mathrm{x}$ & & & $x$ & & \\
\hline A. pentacanthum & $\mathrm{x}$ & $\mathrm{x}$ & & & $\mathrm{x}$ & $\mathrm{x}$ & $\mathrm{x}$ \\
\hline A. quadrispinum & $\mathrm{x}$ & $\mathrm{x}$ & $x$ & $\mathrm{x}$ & $\mathrm{x}$ & & $\mathrm{x}$ \\
\hline Bicosta minor (form A) & $\mathrm{x}$ & $\mathrm{x}$ & & $\mathrm{x}$ & $x$ & & \\
\hline B. spinifera & 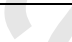 & 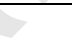 & & & & $\mathrm{x}$ & \\
\hline Campyloacantha imbricata & $\mathrm{x}$ & $\mathrm{x}$ & $\mathrm{x}$ & $\mathrm{x}$ & $\mathrm{x}$ & & \\
\hline C. spinifera & $\mathrm{x}$ & $\mathrm{x}$ & $\mathrm{x}$ & & & $\mathrm{x}$ & $\mathrm{x}$ \\
\hline Calliacantha magna* & $\mathrm{x}$ & $\mathrm{x}$ & & $x$ & $\mathrm{x}$ & & \\
\hline C. natans & & & & & & $\mathrm{x}$ & \\
\hline C. simplex & $\mathrm{x}$ & $\mathrm{x}$ & $\mathrm{x}$ & $\mathrm{x}$ & $\mathrm{x}$ & $\mathrm{x}$ & $\mathrm{x}$ \\
\hline Conioeca boonruangii* & $\mathrm{x}$ & $\mathrm{x}$ & & $x$ & $\mathrm{x}$ & & \\
\hline Cosmoeca ceratophora & $\mathrm{x}$ & $\mathrm{x}$ & $\mathrm{x}$ & $x$ & $x$ & $x$ & $\mathrm{x}$ \\
\hline C. norvegica & $x$ & $\mathrm{x}$ & $x$ & $x$ & $x$ & $\mathrm{x}$ & $\mathrm{x}$ \\
\hline C. phuketensis & $x$ & $\mathrm{x}$ & $\mathrm{x}$ & $\mathrm{x}$ & $x$ & & $\mathrm{x}$ \\
\hline C. subulata & $x$ & $\mathrm{x}$ & & & $\mathrm{x}$ & & \\
\hline C. ventricosa (incl. form A) & $\mathrm{x}$ & $x$ & $x$ & $x$ & $x$ & $\mathrm{x}$ & $\mathrm{x}$ \\
\hline
\end{tabular}




\begin{tabular}{|l|l|l|l|l|l|l|l|}
\hline C. ventricosa (form B) & $\mathrm{x}$ & $\mathrm{x}$ & $\mathrm{x}$ & & $\mathrm{x}$ & $\mathrm{x}$ & $\mathrm{x}$ \\
\hline C. ventricosa (form C) & $\mathrm{x}$ & $\mathrm{x}$ & $\mathrm{x}$ & $\mathrm{x}$ & $\mathrm{x}$ & & \\
\hline Crucispina cruciformis & $\mathrm{x}$ & $\mathrm{x}$ & $\mathrm{x}$ & & & $\mathrm{x}$ & $\mathrm{x}$ \\
\hline Nannoeca mexicana* & & $\mathrm{x}$ & & & & $\mathrm{x}$ & \\
\hline N. minuta & $\mathrm{x}$ & $\mathrm{x}$ & $\mathrm{x}$ & $\mathrm{x}$ & $\mathrm{x}$ & $\mathrm{x}$ & $\mathrm{x}$ \\
\hline N. minuta (form A) & $\mathrm{x}$ & & & & $\mathrm{x}$ & & \\
\hline Saroeca attenuata & & & $\mathrm{x}$ & & $(\mathrm{x})$ & & \\
\hline S. paucicostata & $\mathrm{x}$ & $\mathrm{x}$ & $\mathrm{x}$ & & & $\mathrm{x}$ & $\mathrm{x}$ \\
\hline Stephanoeca andemanica* & $\mathrm{x}$ & $\mathrm{x}$ & & & & & \\
\hline S. apheles & $\mathrm{x}$ & $\mathrm{x}$ & & & & & \\
\hline S. broomia* & $\mathrm{x}$ & $\mathrm{x}$ & & & & & \\
\hline S. diplocostata var. paucicostata & & $\mathrm{x}$ & & & & & \\
\hline S. naja* & $\mathrm{x}$ & $\mathrm{x}$ & $\mathrm{x}$ & & $\mathrm{x}$ & $\mathrm{x}$ & \\
\hline S. supracostata & $\mathrm{x}$ & & & & & & \\
\hline
\end{tabular}

